\title{
PENGEMBANGAN HANDOUT TAKSONOMI TUMBUHAN II BERDASARKAN HASIL IDENTIFIKASI TUMBUHAN MANGROVE DI KAWASAN PULAU BAAI KOTA BENGKULU
}

\author{
Arum Ultanitika ${ }^{1^{*}}$, Kasrina $^{1}$, Irdam Idrus ${ }^{1}$ \\ ${ }^{1}$ Program Studi Pendidikan Biologi, Fakultas Keguruan dan Ilmu Pendidikan, Universitas Bengkulu \\ Email: ultanitikaarum05@gmail.com
}

\begin{abstract}
Abstrak
Bahan ajar Handout merupakan bahan ajar yang berisikan ringkasan yang bersifat sistematis dari beberapa literatur yang relevan dengan materi yang akan diajarkan sehingga membuat mahasiswa akan mudah dalam mengikuti pembelajaran. Adanya Handout hasil penelitian ini diharapkan akan mempermudah dalam memberikan bantuan informasi atau materi pembelajaran sebagai pegangan bagi mahasiswa pada mata kuliah Taksonomi Tumbuhan II. Pembelajaran biologi akan lebih menarik karena contoh-contoh yang akan dikembangkan dalam Handout berasal dari lingkungan. Pada Handout yang dikembangkan oleh peneliti berisikan hasil identifikasi terhadap jenis-jenis mangrove yang ada di Pulau Baai. Setelah dikembangkan, maka dilakukan penenlitian untuk melihat bagaimana kelayakan Handout tersebut. Penelitian dilakukan pada bulan Desember 2018 hingga Mei 2019 dengan uji keterbacaan pada Mahasiswa Pendidikan Biologi Universitas Bengkulu. Berdasarkan penelitian yang telah dilakukan, hasil uji validasi Handout yang dilakukan oleh 1 orang validator materi dan 1 orang validator bahan ajar mendapatkan hasil validasi bahan ajar $81 \%$ dengan kriteria valid dan hasil validasi materi $86 \%$ dengan kriteria sangat valid sehingga didapatkan rata-rata dari kedua validasi yaitu $83,73 \%$ dengan kriteria valid. Pada hasil uji keterbacaan mahasiswa didapatkan hasil $83 \%$ dengan kriteria valid sehingga Handout yang telah dikembangkan, layak digunakan namun perlu dilakukan revisi kecil agar dapat digunakan sebagai bahan ajar.
\end{abstract}

Kata Kunci: Bahan Ajar, Handout, Taksonomi Tumbuhan, Mangrove

\begin{abstract}
Teaching materials Handouts are teaching materials that contain systematic summaries of some literature that are relevant to the material to be taught so that students will find it easy to follow the lessons. It is hoped that this research result Handout will make it easier to provide information assistance or learning materials as a guide for students in the Plant Taxonomy II course. Biology learning will be more interesting because the examples that will be developed in the Handout come from the environment. The Handout developed by the researcher contains the results of identification of the types of mangroves on Baai Island. After being developed, a study was conducted to see how the Handout was feasible. The research was conducted from December 2018 to May 2019 with a legibility test for Biology Education Students at the University of Bengkulu. Based on the research that has been done, the results of the Handout validation test conducted by 1 material validator and 1 teaching material validator get $81 \%$ validation results of teaching materials with valid criteria and $86 \%$ validation results with very valid criteria so that the average of the two validation is $83.73 \%$ with valid criteria. In the student readability test results obtained $83 \%$ with valid criteria so that the Handout that has been developed is suitable for use, but it needs to be made a small revision so that it can be used as teaching material.
\end{abstract}

Keywords: Handout, Teaching Materials, Plant Taxonomy Mangroves 


\section{PENDAHULUAN}

Kurikulum adalah sebuah program yang disusun secara terencana dan sistematis yang dibuat untuk mendukung sebuah proses pendidikan dalam sebuah lembaga pendidikan. Program Studi merumuskan kurikulum yang dikaitkan dengan deskripsi dari mata kuliah dan capaian pembelajaran yang dituliskan dalam bentuk tujuan pembelajaran. Capaian pembelajaran dapat direalisasikan dengan memaksimalkan tercapainya tujuan pembelajaran. Kegiatan belajar mengajar yang diselenggarakan harus dapat mencapai tujuan pembelajaran. Menurut Sanjaya (2011) bahwa pada pembelajaran harus menghantarkan peserta didiknya mencapai kompetensi yang telah ditentukan. Usaha yang dilakukan untuk memaksimalkan tercapainya kompetensi yaitu memperbaiki penyelenggaraan pembelajaran. Paidi (2008) menuturkan bahwa proses pembelajaran membutuhkan perbaikan secara berkala karena mempengaruhi tercapainya tujuan pembelajaran.

Undang-Undang Nomor 12 Tahun 2012 pasal 41 menerangkan bahwa suatu perguruan tinggi wajib menyediakan serta memfasilitasi sumber belajar dan bahan ajar bagi mahasiswa (Pemerintah Indonesia, 2012). Menurut Ngalimun (2014) penentuan bahan ajar penting dilakukan untuk mencapai tujuan pendidikan tertentu. Bahan ajar disusun berdasarkan sumber belajar yang tersedia dan dilakukan oleh dosen.

Bahan ajar Handout merupakan bahan ajar yang berisikan ringkasan yang bersifat sistematis dari beberapa literatur yang relevan dengan materi yang akan diajarkan sehingga membuat mahasiswa akan mudah dalam mengikuti pembelajaran. Menurut Prastowo (2015) Handout merupakan suatu bahan ajar yang tergolong yang paling sederhana, karena hanya memilki dua unsur yaitu identitas Handout dan materi pokok sedangkan pada bahan ajar yang lainnya rata-rata memiliki dari empat unsur. Pengembangan Handout menjadi bahan ajar yang efektif dan inovatif sangatlah penting, karena dengan Handout yang efektif dapat meningkatkan keingintahuan mahasiswa mengenai materi dan membuat mahasiswa ingin terus belajar. Adapun tujuan dari Handout yaitu, untuk memperlancar dan memberikan bantuan informasi atau materi pembelajaran sebagai pegangan bagi mahasiswa pada saat pertemuan perkuliahan (Bakhruddin, 2012). Pembelajaran biologi akan lebih menarik karena contoh-contoh yang akan dikembangkan dalam Handout berasal dari lingkungan atau menyesuaikan dengan potensi daerah disekitarnya.

Potensi lokal yang dimiliki oleh Kota Bengkulu yaitu jenis tumbuhan mangrove. Pulau Baai merupakan salah satu kawasan yang memilki hutan mangrove yang cukup luas dengan berbagai jenis tumbuhan mangrove di dalam nya seperti Rhizophora mucronata, Bruguiera cylindrica, Avicennia marina, Sonneratia alba, Lumnitzera littorea (Febriansyah, 2018).

Penelitian bertujuan mengembangkan Handout yang berisikan tentang hasil identifikasi jenis-jenis mangrove yang ada di Pulau Bai berdasar studi morfologi dan uji fitokimia. Hasil penelitian dari jenis tumbuhan mangrove dapat dimanfaatkan sebagai sumber belajar dalam mata kuliah Taksonomi Tumbuhan II pada materi sumber bukti taksonomi di Program Studi Pendidikan Biologi FKIP Universitas Bengkulu. Mahasiswa dapat melatih 
menyusun deskripsi dan mengidentifikasi dari data sumber bukti jenis tumbuhan mangrove yang terdapat pada Handout yang telah dikembangkan.

\section{METODE}

Jenis penelitian ini merupakan penelitian dan pengembangan (Research and Development). Penelitian dan pengembangan adalah suatu proses atau langkah-langkah untuk mengembangkan suatu produk. Menurut Borg dan Gall (1983) penelitian dan pengembangan merupakan suatu proses yang digunakan untuk mengembangkan produk tertentu dan menguji kefektifan produk tersebut. Pengembangan didasarkan pada temuan uji coba lapangan. Langkah-langkah penggunaan metode penelitian dan pengembangan disesuaikan dengan kebutuhan penelitian, namun tetap berpedoman pada Borg dan Gall (1983), yang terdiri dari 10 tahap yaitu identifikasi masalah, pengumpulan data, desain produk, validasi desain, revisi desain, ujicoba produk, revisi produk, ujicoba pemakaian, revisi produk, dan produksi massal. Pada penelitian ini hanya dibatasi sampai tahap revisi produk.

Subjek penelitian adalah mahasiswa semester IVb Prodi Pendidikan Biologi Universitas yang telah menempuh matakuliah Taksonomi Tumbuhan II. Objek penelitian adalah Handout dan mangrove. Instrumen untuk mengetahui kevalidan dan keterbacaan Handout yang telah dikembangkan peneliti adalah lembar angket validasi dan uji keterbacaan. Uji validasi Handout dilakukan oleh dua dosen validator yaitu 1 validator bahan ajar, dan 1 validator materi serta uji keterbacaan dilakukan oleh mahasiswa semester IVb Program Studi Pendidikan Biologi
Universitas Bengkulu. Analisis hasil penilaian validasi dan analisis hasil uji keterbacaan dilakukan dengan menghitung skor rata-rata dari setiap aspek dengan menggunakan rumus :

$$
\begin{aligned}
\stackrel{\text { Jumlah skor lembar validasi }}{\text { Skor maksimal }} \times 100 \% \\
\text { (Riduwan ,2015). }
\end{aligned}
$$

Data yang diperoleh dikonversi menjadi nilai dengan kriteria interpretasi skor Handout pada Tabel 1.

\begin{tabular}{|c|c|c|c|}
\hline $\begin{array}{c}\text { LKPD } \\
\text { Persentase }\end{array}$ & $\begin{array}{c}\text { Kriteria } \\
\text { respon } \\
\text { kelayakan }\end{array}$ & $\begin{array}{c}\text { Kriteria } \\
\text { respon } \\
\text { keterbacaan }\end{array}$ & $\begin{array}{c}\text { Kriteria } \\
\text { respon } \\
\text { efektivitas }\end{array}$ \\
\hline $0 \%-20 \%$ & $\begin{array}{c}\text { Sangat } \\
\text { Tidak Layak }\end{array}$ & $\begin{array}{c}\text { Sangat Tidak } \\
\text { Baik }\end{array}$ & $\begin{array}{l}\text { Sangat } \\
\text { Tidak } \\
\text { Efektif }\end{array}$ \\
\hline $21 \%-40 \%$ & Tidak Layak & Tidak Baik & $\begin{array}{c}\text { Tidak } \\
\text { Efektif }\end{array}$ \\
\hline $41 \%-60 \%$ & $\begin{array}{l}\text { Cukup } \\
\text { Layak }\end{array}$ & Cukup Baik & $\begin{array}{l}\text { Cukup } \\
\text { Efektif }\end{array}$ \\
\hline $61 \%-80 \%$ & Layak & Baik & Efektif \\
\hline $81 \%-100 \%$ & $\begin{array}{l}\text { Sangat } \\
\text { Layak }\end{array}$ & Sangat Baik & $\begin{array}{l}\text { Sangat } \\
\text { Efektif }\end{array}$ \\
\hline
\end{tabular}

Tabel 1. Interpretasi Skor Handout

(Riduwan, 2015).

Teknik pengumpulan data tanggapan mahasiswa menggunakan lembar instrumen angket untuk melakukan uji keterbacaan. Data hasil uji keterbacaan yang didapatkan merupakan data kuantitatif yang akan diubah menjadi data kualitatif. Digunakan rumus sebagai berikut untuk mengolah data yang diperoleh dari hasil uji tersebut:

$$
\frac{\text { Jumlah hasil pengumpulan data }}{\text { Skor maksimal }} \times 100 \%
$$

(Akbar, 2013).

Hasil dari analisis data yang berupa presentase tersebut kemudian diinterprestasikan pada Tabel 1. 


\section{HASIL DAN PEMBAHASAN}

Berdasarkan hasil validasi oleh validator (ahli materi dan ahli bahan ajar) serta uji keterbacaan oleh mahasiswa. Desain Handout ini disusun mengikuti panduan penyusunan para ahli (Sliriwati,2010; Chairil, 2009). Desain Handout yang dikembangkan ini, dikategorikan sangat layak oleh para validator dengan nilai rata-rata $83,73 \%$, dapat dilihat pada Tabel 2, dan juga dinilai sangat baik dengan nilai rata-rata $83 \%$ oleh mahasiswa dalam uji keterbacaan dapat dilihat pada Tabel 3.

Tabel 2. Hasil Uji Kelayakan Desain Handout oleh Validator

\begin{tabular}{clcc}
\hline No & Validator & Persentase & Kriteria \\
\hline 1. & $\begin{array}{l}\text { Validator } \\
1 \text { (Ahli }\end{array}$ & $86 \%$ & $\begin{array}{c}\text { Sangat } \\
\text { Layak }\end{array}$ \\
2. & $\begin{array}{l}\text { Materi) } \\
\text { Validator } \\
2 \text { (Ahli } \\
\text { Bahan } \\
\text { ajar) }\end{array}$ & $81 \%$ & $\begin{array}{c}\text { Sangat } \\
\text { Layak }\end{array}$ \\
\hline & & \\
\hline Rata-rata & $83,73 \%$ & $\begin{array}{l}\text { Sangat } \\
\text { persentase }\end{array}$ \\
\hline
\end{tabular}

Berdasarkan saran dan arahan dari kedua validator, dilaukan revisi terhadap desain Handout. Beberapa poin yang perlu dirubah sebelum dilanjutkan keuji keterbacaan oleh mahasiswa yaitu :

1) Pemberian judul Handout yang lebih ditekankan pada isi Handout

2) Point pada halaman Identitas Handout harus lebih detail dengan adanya penambahan point kode mata kuliah

3) Pada Halaman pemetaan Capaian Pembelajaran. Indikator dan tujuan pemebelajaran harus sesuai dengan capaian pembelajaran materi pada mata kuliah yang bersangkutan

4) Penjelasan materi atau keterangan di awal tabel
Berdasarkan perbaikan yang telah dilakukan maka dibawah ini terdapat perbandingan Handout sebelum divalidasi dan setelah divalidasi yaitu :

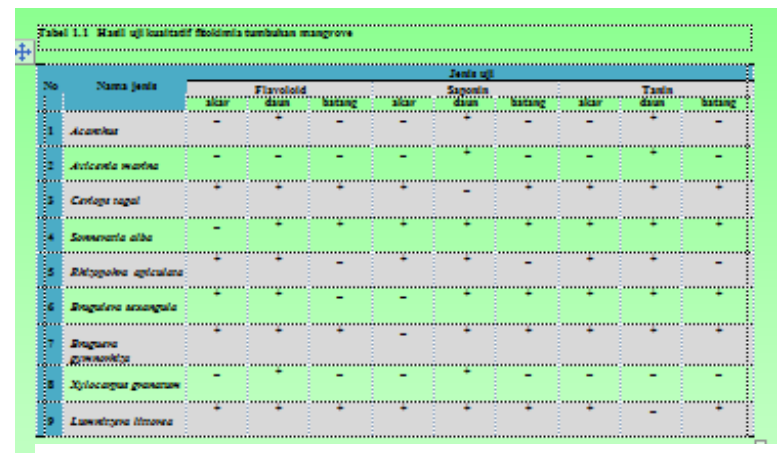

Gambar 1. 1 Halaman 27 sebelum revisi

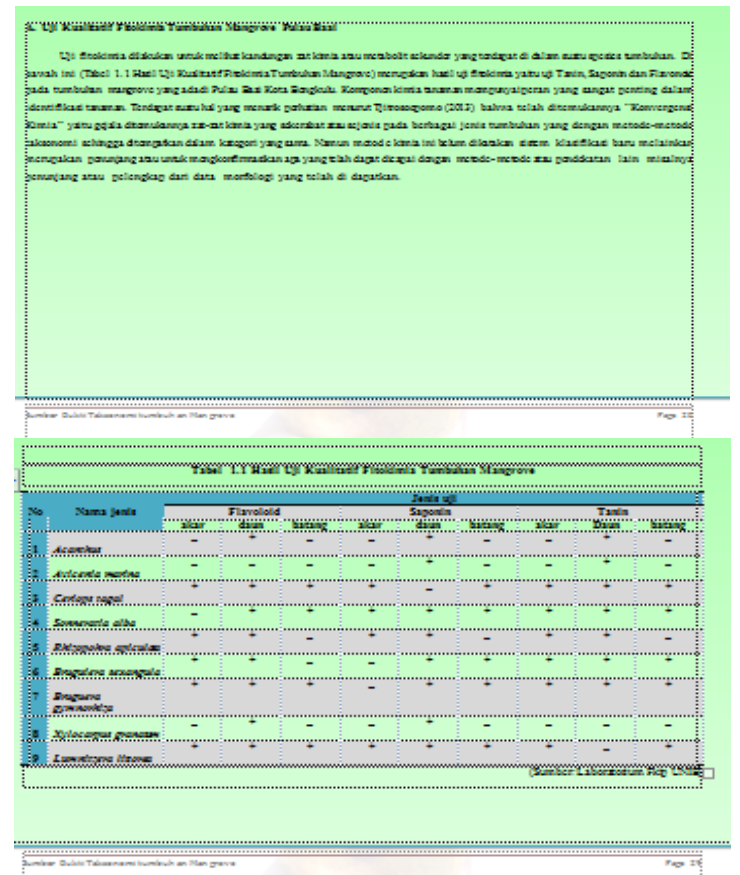

Gambar 2.2 Halaman 27-28 setelah revisi

Pada presentase keidelan Handout dari aspek kelayakan bahan terdapat 4 aspek yang di nilai yaitu aspek desain isi, kesesuian media dengan kelompok sasaran, organisasi Penyajian Umum, Penulisan. Secara berurutan hasil analisis pada setiap aspeknya adalah 75\%, 88\%, 88\%, 75\% dengan rata-rata $81 \%$. Adapun revisi Handout dari validator bahan ajar yaitu : 


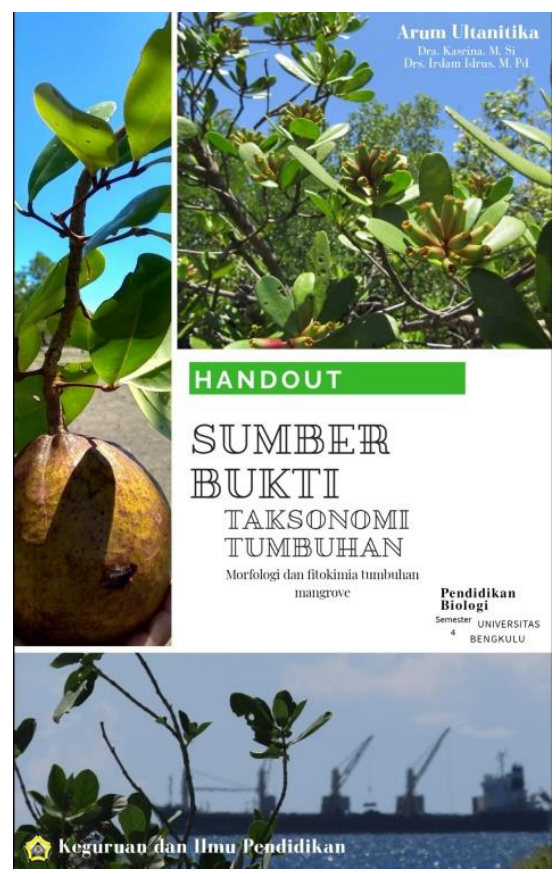

Gambar. 3 Cover sebelum revisi

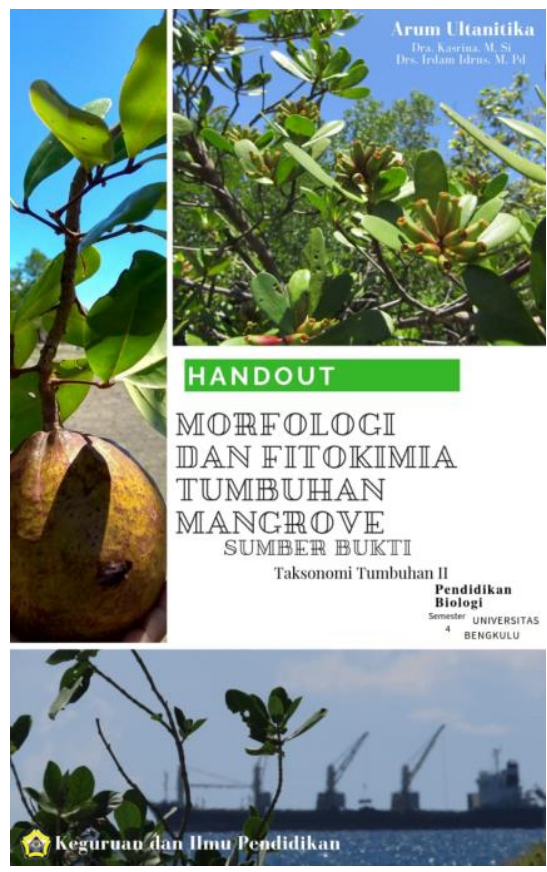

Gambar 4. Cover setelah revisi

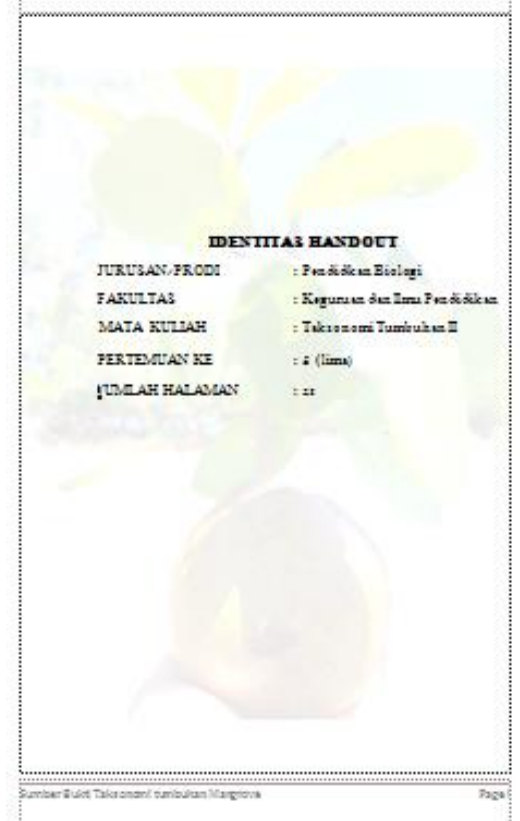

Gambar 5. Halaman ii sebelum revisi

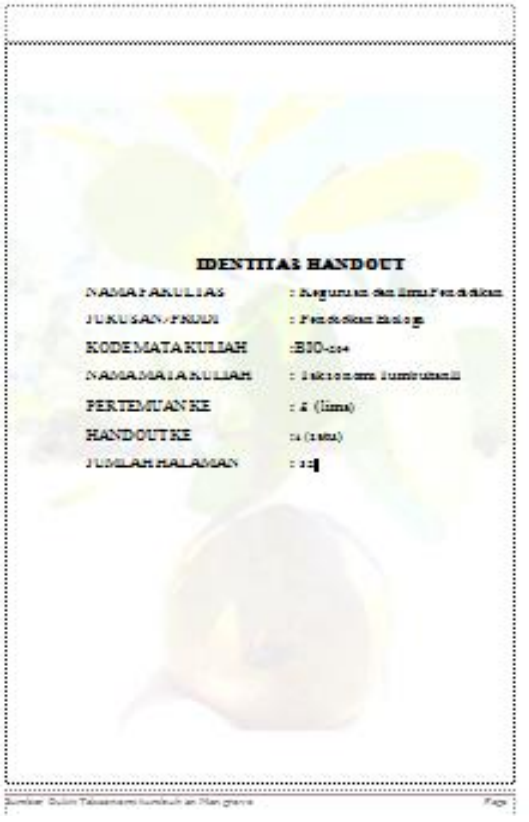

Gambar 6. Halaman ii setelah revisi 


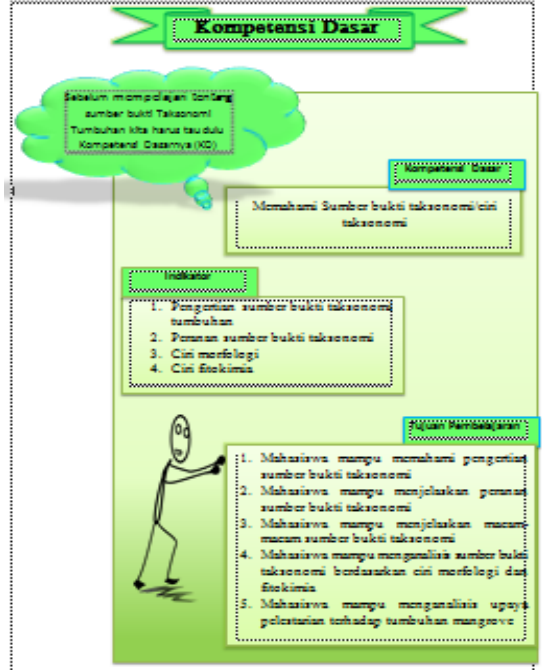

Gambar 7. Halaman v sebelum revisi

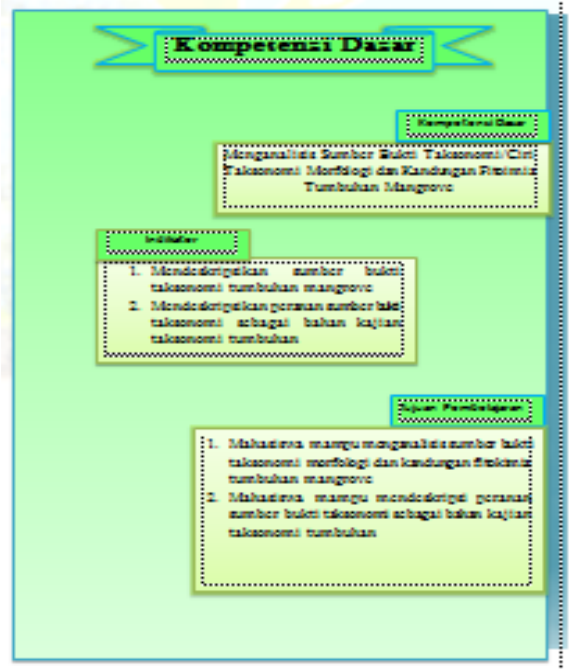

Gambar 8.4 Halaman v setelah revisi

Dengan demikian, Handout hasil pengembangan dari observasi pengamatan morfologi dan uji fitokimia pada tumbuhan mangrove Pulau Baai Kota Bengkulu layak untuk uji keterbacaan pada mahasiswa setelah revisi berdasarkan saran dari validator. Dibawah merupakan hasil uji keterbacaan (Tabel 3).
Tabel 3. Hasil Uji Keterbacaan Handout

\begin{tabular}{clccl}
\hline No. & $\begin{array}{l}\text { Aspek } \\
\text { Pengamatan }\end{array}$ & Skor & Persentase & $\begin{array}{l}\text { Kriteria } \\
\text { Validasi }\end{array}$ \\
\hline 1 & $\begin{array}{l}\text { Kelayakan } \\
\text { Materi atau Isi }\end{array}$ & 872 & $83 \%$ & $\begin{array}{l}\text { Sangat } \\
\text { baik }\end{array}$ \\
2 & $\begin{array}{l}\text { Komponen } \\
\text { Bahasa } \\
\text { Komponen } \\
\text { Grafika }\end{array}$ & 436 & $83 \%$ & $\begin{array}{l}\text { Sangat } \\
\text { baik } \\
\text { Sangat } \\
\text { baik }\end{array}$ \\
\hline Rata-Rata & 441 & $84 \%$ & $\begin{array}{l}\text { Sangat } \\
\text { baik }\end{array}$ \\
\hline
\end{tabular}

Berdasarkan hasil analisis uji keterbacaan oleh mahasiswa semester IVb Pendidikan Biologi yang berjumlah 44 orang di dapatkan bahwa persentase penilaian 83\% dengan kriteria penilaian Sangat baik. Persentase penilaian ini dilihat dari 3 aspek yaitu aspek Kelayakan materi/isi, Komponen Bahasa, dan Komponen Grafika. Hasil analisis persentase pada setiap aspek uji keterbacaan secara berurutan, yaitu $83 \%$, $83 \%$ dan $84 \%$ dengan rata-rata $83 \%$.

Handout hasil pengembangan ini dinyatakan layak untuk langsung digunakan dalam proses pembelajaran. Desain Handout ini merupakan adopsi dari Rozalia (2018) dan telah melalui 2 tahap validasi yaitu validasi materi dan validasi bahan ajar sebelum dilakukannya uji keterbacaan pada mahasiswa. Menurut Widyaningsih (2013) yang diharapkan dari validasi adalah masukan perbaikan Handout. Saran yang diberikan oleh validator adalah acuan untuk perbaikan produk Handout tersebut agar sesuai dengan aspek-aspek pembelajaran, seperti tujuan pembelajaran, kegiatan Handout, tampilan Handout dan pertanyaan analisis. Akbar (2013) juga menguatkan, bahwa Handout memang seharusnya memenuhi syarat konstruksi terkait kejelasan Struktur kalimat, penggunaan bahasa, keselarasan antara tujuan pembelajaran. 
Pada uji validasi oleh validator materi Handout dinyatakan sangat layak oleh validator dengan nilai rata-rata $86,46 \%$. Dengan aspek penilaian validator materi yaitu terdiri dari 4 aspek penilaian yaitu:

1) Kesesuaian topik pada Handout dengan materi Sumber Bukti Taksonomi Tumbuhan II,

2) Kualitas materi,

3) Kualitas gambar

4) Pemaparan hasil penelitian.

Ditinjau dari aspek kesesuaian topik pada Handout dengan materi Sumber Bukti Taksonomi Tumbuhan II penilaian yang diberikan oleh validator termasuk ke dalam kriteria sangat valid dengan nilai rata-rata $87,50 \%$. Hal ini menunjukan bahwa topik yang diangkat pada Handout seperti penelitian morfologi dan uji kandungan fitokimia pada mangrove telah sesuai dengan Capaian Pembelajaran materi sumber bukti yang akan di sampai dalam perkuliahan Taksonomi Tumbuhan II. Hal ini dipertegas oleh Prastowo (2011) yang mengatkan bahwa dalam membuat suatu bahan ajar maka diharapkan bahan ajar tersebut benar-benar mampu membuat peserta didik menguasai kompetensi yang telah ditentukan.

Ditinjau dari aspek kualitas materi berisikan komponen yang berhubungan dengan isi Handout yang sesuai dengan literatur, materi yang disediakan pada Handout merupakan materi yang mutakhir, dan peran Handout yang memberikan inovasi yang baru terhadap perkuliahan pada mata kuliah Taksonomi Tumbuhan II. Berdasarkan analisis penilaian yang diberikan oleh validator dari ke 3 komponen pada aspek kualitas materi maka didapatkan nilai rata-rata $83 \%$ dan dinyatakan sangat layak. Hal ini sesuai dengan yang katakan oleh Prastowo (2011) bahwa dalam suatu bahan ajar maka informasi pendukung berupa literatur itu sangat penting karena dengan banyaknya literatur yang di pakai dalam pembuatan suatu bahan ajar akan membuat peserta didik memperoleh pengetahuan yang komprehensif.

$\begin{array}{lrr}\text { Ditinjau } & \text { dari } & \text { aspek kualitas } \\ \text { gambar berisikan } & 2 & \text { komponen } \\ \text { penilaiannya yaitu } & \text { gambar } & \text { yang }\end{array}$
ditampilkan memiliki kualitas yang jelas dilihat dan gambar yang tersedia di dalam Handout memperjelas materi yang di sampaikan memiliki nilai rata-rata $75 \%$ dengan katagori layak dari validator materi. Hal ini sejalan yang dikatakan Angkowo \& Kosasih (2007) bahwa gambar berfungsi untuk menarik perhatian, memperjelas ide, mengilustrasikan atau memberikan variasi pada fakta kemungkinan akan dilupakan atau diabaikan oleh peserta didik. Hal ini sejalan yang dinyatakan oleh Komalasari (2011) bahwa gambar mampu memberikan motivasi kepada peserta didikdalam proses pembelajaran. Terakhir pada aspek pemaparan hasil penelitian yang berisikan komponen penilaiannya yaitu analisis data morfologi dan fitokimia tumbuhan mangrove yang di buat dalam Handout tersusun dengan jelas atau tidak. Hasil analisis penilaian di dapat pada aspek pemaparan hasil penelitian di dapat ratarata nilai $100 \%$ dengan kriterian penilaian sangat layak.

Berdasarkan aspek penilaian oleh validator bahan ajar terdiri 3 bagian penilaian yaitu isi, grafis dan bahasa. Pada bagian Isi terdapat 2 bagian penilaian yaitu aspek desain isi dan aspek kesesuaian media dengan kelompok sasaran. Pada desain isi terdapat 4 indikator penilaian yaitu : (1) ketepatan penempatan unsur tata 
letak (topik, sub topik dan ilustrasi); (2) kesesuaian urutan antar sub topik; (3) kesesuaian semua ilustrasi berupa gambar yang ditampilkan dalam Handout; (4) kesistematisan hirarki topik sehingga memudahkan pemahaman menjadi berurut. Penilaian pada aspek validator bahan ajar ini mendapatkan rata-rata persentase nilai $75 \%$ dengan kriteria penilaian layak.

Pada aspek kesesuaian media dengan kelompok sasaran terdapat 2 indikator penilaian yaitu kesesuaian media dengan sasaran pengguna (mahasiswa) dan kesesuaian kegiatan mahasiswa degan materi yang disajikan. Berdasarkan hasil analisis penilaian pada aspek ini rata-rata persentase penilaian yang didapat yaitu $88 \%$ dengan kriteria penilaian sangat layak.

Pada bagian penyajian/ kegrafisan terdapat aspek yang dinilai yaitu aspek organisasi penyajian yang terdiri dari 2 indikator penilaian yaitu Handout disusun secara sistematis (cover, pendahuluan,isi dan penutup) dan penyajian gambar dan warna pada Handout. Berdasarkan hasil analisis penilaian yang di dapatkan persentase penilaian pada aspek ini adalah $88 \%$ dengan kategori penilaian sangat layak. Bagian yang terakhir adalah bahasa terdapat aspek penilaian penulisan yang terdiri dari 3 indikator penilaian yaitu: (1) Handout nyaman untuk dibaca, jenis, ukuran, dan spasi huruf sudah sesuai; (2) bahasa penulisan sudah jelas; (3) bahasa yang digunakan sudah sesuai dengan sasaran dan komukatif. Hasil analisis penilaian pada aspek ini maka di dapatkan persentase penilaian yaitu $75 \%$ dengan kriteria penilaian layak.

Berdasarkan hasil analisis penilaian dari setiap aspek tersebut maka didapatkan persentase rata-rata penilaian dari kedua validator yaitu $86,46 \%$ oleh validator materi dan $81 \%$ oleh validator validator bahan ajar (Gambar 2). Rata-rata dari hasil penilaian kedua validator di dapatkan yaitu $83,73 \%$ sehingga Handout dapat dikriteriakan layak dilakukan uji keterbacaan terhadap mahasiswa namun masih membutuhkan revisi kecil. Hal ini sesuai dengan Akbar(2013) bahwa jika kriteria validasi berada pada rentang 71$85 \%$ dikatakan layak namun membutuhkan revisi kecil.

Uji keterbacaan Handout dilakukan oleh 44 mahasiswa semester IVb Pendidikan Biologi Universitas Bengkulu. Berdasarkan analisis uji keterbacaan, persentase penilaian Handout yaitu $83 \%$ dengan ratarata persentase penilaianr dapat dilihat pada Tabel 3. Aspek yang dinilai pada uji keterbacaan yaitu Kelayakan materi, Komponen Bahasa dan Komponen Grafika. Pada aspek kelayakan materi terdapat 6 indikator penilaian yaitu :

1) Materi jelas dan mudah untuk dipahami

2) Isi atau materi dapat menambah wawasan mengenai sumber bukti taksonomi tumbuhan II

3) Isi Materi menarik untuk dibaca atau diketahui

4) Gambar yang digunakan memiliki kejelasan kelengkapan keterangan sehingga memudahkan untuk memahami isi bacaan

5) Penyajian daftar pustaka jelas

6) Penyajian materi.

Persentase penilaian yang didapatkan pada aspek penilaian kelayakan materi/isi pada Handout adalah $83 \%$ dengan kriteria penilaian sangat baik. Persentase penilaian yang didapatkan pada aspek penilaian kelayakan materi/isi pada 
Handout adalah 83\% dengan kriteria penilaian sangat baik.

Kedua aspek komponen bahasa terdapat 3 indikator penilaian yaitu bahasa yang digunakan komunikatif, bahasa yang digunakan mempermudah memahami isi bacaan, serta penggunaan kalimat efektif atau tidak ambigu. Persentase dari hasil uji keterbacaan pada aspek komponen bahasa di dapatkan yaitu $84 \%$ dengan kriteria sangat baik. Aspek penilaian pada uji keterbacaan yang terakhir adalah komponen grafika. Indikator penilaian pada aspek ini terdapat 3 indikator yaitu penyusunan layout dan desain cover atau sampul menarik, tata letak gambar atau tulisan jelas dan baik, dan hasil cetakan berkualitas baik dan jelas.

Rata-rata hasil persentase dari ketiga aspek penilaian pada uji keterbacaan Handout ini yaitu $83 \%$ dengan kriteria penilaian sangat baik sehingga Handout dapat digunakan sebagai media pembelajaran pada perkuliahan Taksonomi Tumbuhan II. Hal ini sesuai dengan Akbar (2013) yang menyatakan bahwa media pembelajaran dapat dikatakan layak bila rata-rata persentase dari angket validasi validator media, validator materi dan respon siswa diatas $70 \%$.

Kritik serta saran yang didapatkan dari mahasiswa semester IVb sebagai responden bermacam-macam. Terdapat kritik tentang beberapa kata di dalam Handout yang sulit dimengerti oleh mahasiswa dan penambahan gambar yang lebih menarik dan jelas agar mahasiswa lebih tertarik dan lebih mudah mengerti materi yang disampaikan dalam Handout Morfologi dan Fitokimia Tumbuhan Mangrove sebagai Sumber Bukti Taksonomi Tumbuhan II ini. Disimpulkan bahwa dari kritik serta saran yang telah diberikan oleh mahasiswa, ternyata mahasiswa sangat menyukai bacaan yang menarik dengan memiliki banyak gambar serta kalimat yang mudah dicerna untuk menambah daya tarik dari pembaca. Hal ini sesuai dengan pendapat (Suharnan, 2005) yang mengatakan bahwa didalam sebuah buku yang terdapat banyak gambar didalamnya dapat membuat materi bacaan lebih menarik perhatian untuk di baca karena pembaca dapat dibuat berimajinasi dengan gambar - gambar yang tersedia tersebut. Berimajinasi dapat membantu seseorang dalam daya ingatnya.

Handout yag dikembangkan oleh peneliti memiliki beberapa keunggulan dibandingkan dengan Handout dari penerbit yaitu dari aspek desain tampilan, aspek materi dan aspek komponen penyusunannya. Keunggulan utama Handout ini disusun berdasarkan sumber lingkungan sekitar sehingga lebih aplikatif dan bermakna. Selain itu juga, dapat meningkatkan motivasi peserta didik dalam belajar serta meningkatkan kesadaran mahasiswa pada sikap peduli lingkungan. $\mathrm{Hal}$ ini sejalan dengan yang dikatakan Febriansyah (2018) bahwa pendidikan dapat memberikan edukasi kepada mahasiswa agar peduli dengan potensi lokalnya.

\section{PENUTUP}

\section{Simpulan}

Handout hasil pengembangan dari observasi tumbuhan mangrove berdasarkan morfologi dan uji fitokimia valid dan layak digunakan dalam perkuliahan Taksonomi Tumbuhan II pada materi Sumber Bukti Taksonomi Tumbuhan yang dibuktikan dengan hasil persentase validasi sebesar $83,73 \%$ dengan kriteria penilaian sangat 
layak dan analisis persentase uji keterbacaan $83 \%$ dengan kriteria sangat baik sehingga layak digunakan.

Saran

Handout yang telah dikembangkan dapat digunakan untuk penelitian selanjutnya yaitu implementasi atau penerapan bahan ajar untuk mahasiswa semester 4 Pendidikan Biologi pada Materi Sumber Bukti mata kuliah Taksonomi Tumbuhan II.

\section{Daftar Pustaka}

Akbar, S. 2013. Instrumen Perangkat Pembelajaran. Bandung: Remaja Rosdakarya

Angkowo, R. dan A. Kokasih. 2007. Optimalisasi Media Pembelajaran. Jakarta: Grasindo

Bakhruddin. 2012. Pengembangan Bahan Ajar dan Media Pembelajaran. (burhanuddin.net/2012/pengemban gan-bahan-ajar-dan-media) (diakses pada 15 januari 2019)

Borg and Gall. 1983. Educational Research, An Introduction. New York and London: Longman Inc.

Chairil. 2009. Media Pembelajaran. (Online). http://chai-chairil.pdf

Febriansyah., Dede h., Bertoka, F., Person Pesona Renta,Yenni, P. 2018. Struktur Komunitas Hutan Mangrove di Pulau Baai Kota Bengkulu.Jurnal Enggano3,. 113-120.

Komalasari, K. 2011. Pembelajaran Konstektual Konsep dan Aplikasi. Bandung: PT. Refika Aditama
Ngalimun. 2014. Strategi dan Model Pembelajaran. Aswaja pressindo: Yogyakarta

Riduwan. 2013. Skala Pengukuran Variabel Variabel Penelitian. Bandung: Alfabeta

Rozalia, Anifah., Kasrina., Irwandi, A. 2018. Pengembangan Handout Biologi Materi Keanekaragaman Hayat Untuk SMA Kelas X. Jurnal diklabio Pendidikan dan Pembelajaran Biologi. (Online). https://ejournal.unib.ac.id/index.ph p/ippb/article/view/5142.(Diakses tanggal 30 Juli 2019)

Sanjaya,A. 2011. Model-model Pembelajaran. Jakarta: Bumi Aksara

Suharnan.2005. Psikologi Kogniti. Surabaya: Srikandi

Slirawati, 2010. Teknik Penyusunan Handout Pembelajaran (online). http://staff.uny.ac.id/pengembanga n-Handout-dan-bahan ajar.doc (diakses 20 januari 2018)

Undang Undang Republik Indonesia No 20. 2003 Tentang Sistem Pendidikan Nasional. Jakarta.

Paidi. (2007). Peningkatan Scientific Skill Siswa Melalui Implementasi Metode Guided Inquiry pada Pembelajaran Biologi. Yogyakarta : Universitas Negeri Yogyakarta.

Pemerintah Indonesia. 2012. Undangundang Sistem Pendidikan

Prastowo, Andi. 2011. Panduan Kreatif Membuat Bahan Ajar Inovatif. Jogjayakarta : Diva Press 
Widyaningsih, R. 2013. Pengembangan Handout Geografi Berbasis Penanggulangan Bencana Melalui Pembelajaran Contextual Teaching and Learning (CTL) di Kelas XI IPS SMA Negeri 1 Trawas. Artikel Non Publikasi. Diakses tanggal 24 juni 2019 